\title{
Entrepreneurial Culture and Social Assets: A combining Capital for Innovative Village Development at Local Community in Indonesia
}

\author{
Nursyirwan Effendi ${ }^{1}$ \\ \{ nursyirwan@soc.unand.ac.id ${ }^{1}$ \} \\ Faculty of Social and Political Science, Universitas Andalas, Padang, Indonesia
}

\begin{abstract}
A village development needs a few kinds of capitals for making developmental process and ending up enhancing prosperous communities. In the current Indonesia, the issue of village development is mostly indicated by re-role of the central government by injecting "governmental village development fund" (dana desa). Consequently, on the one hand, the central government takes control over village development, and on the other side, any local initiatives should get confirmation and deal with the government's rule and interests in terms of benefiting this development budget. In dealing with this condition, local communities fortunately have already been creative to being independent in life by activating their entrepreneurial culture to articulate their capability in development process and to catch up better-off condition. This entrepreneurial culture is a capital that includes local rural markets, agricultural and artisan trading, fishery activities, local product skills and any other commercial exchanges. This kind of culture is also a part of how local communities regard economic activities as part of their own way of social development. Local communities are also benefiting their social assets as another capital. These assets or mostly common properties are inherited from their ancestor e.g. social forest, land, rice fields etc. These assets are also common property rights as cultural capital in the village development. The paper will deal with a descriptive analysis of capitals that may be used for village development in Indonesian with the case of west Sumatra context. The purpose of the paper is to provide an alternative model of village development which is regarded as an innovative way in Indonesia.
\end{abstract}

Keywords: Village Development, Village Budget, Entrepreneurial Culture, Ethnic.

\section{Introduction}

This article is started from two last issues in economic anthropology that are, firstly economies of ethnicity that is addressed by Eriksen (2005). This issue is about economy practiced among ethnic groups and economies in ethnicity which is studied by using variable of livelihood practiced in the context of poly-ethnic societies and entrepreneurship. These two contexts is based on ethnic and cross border nations that are connected member of the ethnic who are running economic activities based on capitalism either formal or informal (Eriksen, 2005: 353). The 2nd issue is related to the anthropology development that is the participative approach and sustainable development based on culture as Clark already argued on it (2002). This issue starts raised since the early millennium, but in the development of more than a decade this issue is still minimal adopted as mainstream development many countries. Meanwhile, the 
issue of participatory development and sustainable development has been used in the discourse of development since the 1980s, however without including the element of culture in it forever. There have been many understood that sustainable development has been in an international scale, but mostly focus on natural resources and the system of ecology as part of the direction of economic development. Sustainable development is understood as an effort to manage with good nature and the environment for the benefit of future generations. Even though many who forgot that the development is also a cultural process that is run by of the community itself with the variation of their own culture and social pattern, So that, the need for cultural capital in development also important (Clark, 2002: 123). These two issues became important as a basis for implying entrepreneurship factor in the community development (DeHart, 2010) and utilization of the culture as the main asset for the development (see Dove, 2011). As the case, the countries in the world that have been successful in boost the prosperity of its people by the use of the practice of entrepreneurship and sustainable development of community development culturally for capital is Mexico and Honduras. The state capital Mexico has been also using these cases in people Oaxaca (Chibnik, 2002). In these communities, entrepreneurial space opened the craft carve through the utilization of culture, painting and other souvenirs to fill the craft market in the United States.

Concept used is to commercialize the craft (craft commercialization). As a consequence, people in the Oaxaca taught to be entrepreneurial personality (entrepreneurs) and build networking in market and trading cross country (market of evolution niches) (Chibnik, 2002:24). Other countries, such as Honduras and Caribbean, have used social and cultural resources in the form of common property assets, like beach area, to build a large number of stores and business relates to diving tourism, they run many dive shops (Cronk dan Steadman, 2002). Cases regional development managed to boost public welfare held in the community Utila, located on an island in bays along the Caribbean Sea. The community Utila driven build their region through the utilization of natural resources of the sea and beautiful beaches as communal property (Ulayat) by developing skills training commercial diving and provide a variety of the needs and a dive that equipment used to the fullest by tourists from all over the world (Cronk dan Steadman, 2002: 55).

Indonesia also of being a state concerned with issues of culture in community development, because the sociologically at least have 656 ethnic groups who different cultural and social life (Hidayah, 1997) and has character of the pluralistic society and even the multicultural. In the national development, approach culture is not used as the main developmental modal, but using the approach of economics. Culture is used mostly for a union of nations and adhesives among various communities, but not as a stimulant and locomotion ( prime movers ) of the whole national development. However locally or at the regional level, in fact, culture became a strong capital for making dynamics in community development.

One of cultural pictures in Indonesia society is local economy product that uses identity of ethnic and funded by an ancestral estate culture of society, such as is woven (songket), craft engraving, and culinary. Ethnic identity is sticky to the many material products and to conduct business based on ethnic or ethnopreneurship, such as, Aceh embroidery, Minangkabau and Palembang weaving (songket), Nusatenggara clothes (tenun ikat), Jepara dan Bali carving, Betawi coconut rice (nasi uduk), coconut fried beef Padang (rending), Palembang fish balls (mpek-mpek), etc. (Effendi, 2003). It means, the gap between concept used to move development and reality the community clearly visible. On the one hand, development based on concept of economy capitalist. On the other hand, at the reality level, the developmental dynamics is based on culture the peoples. At this point, I argue that for developing communities either at the national or local level, government should have been use cultural capital as one of 
the main, because in line with the existence of reality of an Indonesian society containing the nature as a society which are rich in a number of elements, assets, and of cultural products.

Thus, to build the people in Indonesia, it is extremely necessary to put issues of culture and ethnicity, which was not always economic element, as ever had long publicly stated by Colletta and Kayam (1987). In economies of ethnicity, Eriksen put in two main variables, that of, the entrepreneurial activity and character culture of the tribe to develop community (see Eriksen 2005: 355). These theoretically both variables do not have a direct relationship, but both can be connected against each other in the practice of, for example alteration in form livelihoods which need a change in ethnic identity (Eriksen 2005: 356; Dove 2010: 169). Both variables, in empirical level, can have a direct relationship through the effort to recruit factors in between (intervening) which allegedly can give the shape of a positive relationship between entrepreneurship and ethnicity in an effort to develop community. Theoretically, classical argument underlying study into the ethnicity in the context of entrepreneurial economy is the notion of "the great transformation" from Karl Polanyi (1944), a substantivist anthropologist. According to him, a huge social transformation has happened in society, because of social system has integrated into interest of capitalist market economy, so ethnic groups engage in an commercial activity and change social value orientation to commercial values (see Effendi, 2011).

\section{Village Development at Local Community in Indonesia; The case of west Sumatra Province}

For the context of province of west Sumatra, regional development in which still has identity of ethnic dominant, that is the Minangkabau culture, it is the same as the main current national development which still uses measurement of economy, rather than the size of culture. This province with 13 regencies and 6 municipalities has led to the development of people at the local level in the village scope and nagari since 2007. A development mechanism of the provincial region is badly rely on supply intake budget of the regional income and assistance from the central government, so called top-down budget, or de-concentration funds.

In the present era, development in the village level and nagari lean on financial support the central government known as village funds (Dana Desa). Since the policy was launched by the government of Indonesia since 2015 as the act nr.6 in 2014 about village, local government of province of west Sumatra has been following up it by launching policies of rural development to the nagari basis. It has been also starting by implementing regional regulation (Peraturan Daerah) nr.2 tahun 2007 about Nagari government. By doing so, regional development of west Sumatra is very underlying to the interests of local culture. System of government of nagari venture will be based to strengthening the existence of the prevailing customary law and system. Arrangement of village administration, as stated in article 4 law nr. 6 year 2014 that village or nagari managed to preserve and develop local traditional custom, cultural traditions; and to encourage community initiatives, movement and participation of villagers or to develop their potential and nagari assests to welfare community members. Therefore, the concept of formal legal village or nagari development, now it is been more based on the utilization of the local culture and strengthen participatory process in the community to become the section of a social movement to advance the welfare of the community, than using the measure of an economy alone. 
The implementation of policies for village funds ( dana desa, DD) began from the year 2015 in the whole territory of Indonesia. Of 33 provinces in Indonesia, there are 74.093 villages, the DD provided by the government reaching Rp.20.766.200.000,-. At setting a benchmark in 2016, the number of DD estimated to increase to Rp. .46.982.080, - which has been prepared for the entire villages in which has risen to as many as 74.754 village. To the year of 2017 , these village funds rose again to Rp.60 trillion to a number of villages increased slightly namely 74.954 villages ( Kemenkeu RI, 2016 ).

Relates to the allocation policies for village funds, the province of west Sumatra today having 880 villages and nagari, with in detail consisting of 126 in the form of desa administration and 754 number of nagari administration. To these all the village area and the nagaris in a period of the year 2015, the allocated fund of Rp .267.003.839.000 ,- In 2016 was increased up to Rp. 598.637.609.000,-. Revenue each nagari and village in west Sumatra of DD, it has been calculated in a certain way by the Kemenkeu of Indonesian Republic, then in the year 2015 every nagari received village funds allocation in average of Rp. 600 million. While in 2016, the number of DD being received by each nagari grow to between Rp. 800 million and Rp. 1.2 billion (BPM Sumbar, 2016). According to the Indonesian ministry for monetary (Kemenkeu), the allocation village funds to the west Sumatran province in 2017 rose up to $\mathrm{Rp}$ .720 .442 .000 .000 , - provided to the villages and nagaris in number of 928 .

The number of allocation village funds to rural and nagari development in west Sumatra set by the central government, when compared with other provinces neighbors including still much smaller. In 2015, the province of west Sumatra totaling 5.3 million people with having 880 nagari and village, received DD a year only Rp.600 billion, while Aceh province having the 4 million people and having 6000 villages, received DD up to Rp.5 billion per year (BPM Sumbar, 2016).

Data on development assistance from the central government who wished to make the funds policy where it can be said to have been give strength economic capital at the village level. However, whether this economic capital will satisfy the needs of material and social development each village that will eventually create the welfare of the community? By regarding this question, it is assumed that this is the village funds are still not been able to meet in an optimum manner the level of community welfare. For west Sumatra, village funds received between Rp.600 million to Rp.800 million per year, it can be said is still quite low, compared with a population of nagari varying from 3,500 - 20,000 people. Development needs, for example, road infrastructure, cost about Rp.500 million per km, when village funds will be used just for this construction, so shall perish and be consumed only to such as developing roads. When associated with the increase in community welfare in the village which includes the field of social, economic, culture, education, communication etc., so such. It can be said, that village funds are more as funds the originator (stimulating budget) to build a nagari in west Sumatra. Then, how to build the nagari to be more sustainable and can be accelerated? For this, a breakthrough or innovation needed to be able to build nagari more prosperous than before. In this context, this writing proposed thesis that innovation of nagari development and villages in west Sumatra can be improved the results and continued sustainably through the use of capital of community entrepreneurship and assets of social and cultural factors at the region.

To strengthen the thesis, the common fact is the province of west Sumatra is relatively not enough being able to support regional development costs for village and nagari which are drawn from strategic natural resources, such as oil, plantation, of maritime products and the forest, because this province has much less than if compared to the areas of the province of neighbors such as the province of Riau, south Sumatra or north Sumatra. These provinces have those strategic resources and plantation oil in a very wide. In addition to it, the economic growth of 
west Sumatra is still below four percent per year. It means the strength of public economy is still very low compared with large industrial economy basis. Except, two regency areas in west Sumatra, west Pasaman west Dharmasraya, after more than 15 years developed, now there have been having a large estate and being able to make an impact for the welfare of the community.

Thus, a breakthrough to expedite and accelerate the development nagari is the effort innovative use culture entrepreneurship and the use of assets sociocultural. Because, efforts to these innovative has a lot of moved by the community itself, so the development approach participatory ( participatory development more appropriate used, than the development approach from above ( top-down ). Participatory development give assurance against motivation and encouragement executing development and enjoy the results of development and the whole community members, is no exception participation of a social group that susceptible as poor families, marginal or with disability.

The process of the implementation of development policy or conduct of a nagari and village are meant to be summons in a broad range of activities in our community in concrete. The process of the implementation have led to the goals one trial which was formulated in policy These objectives can provide the basis for the programs established by the government nagari and village. The following is the scheme about development policy based on nagari participatory:

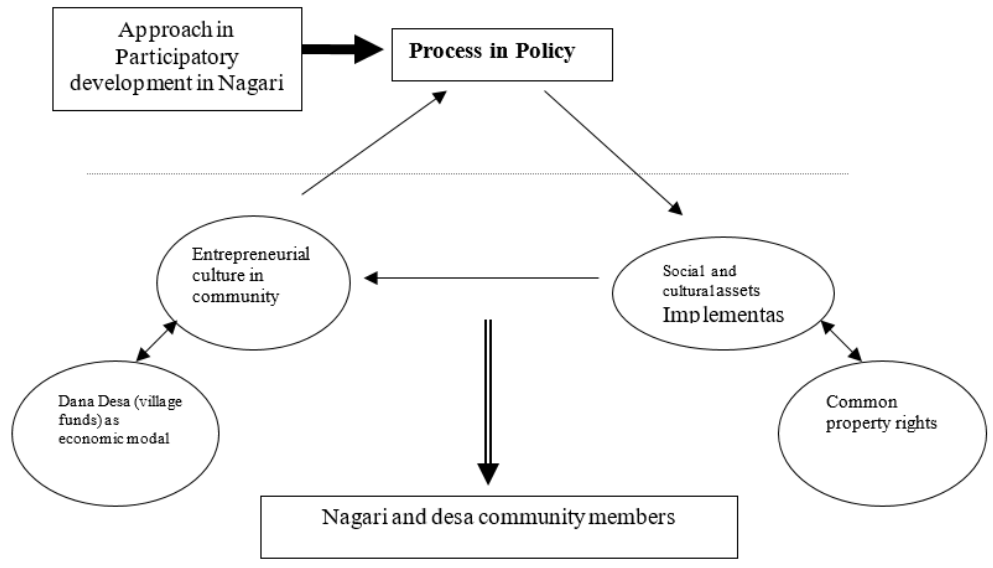

In the context of the province of west Sumatra, smallest area to detect a progress report on the development of society is nagari or village. Especially, nagari is an area of customary law (adat) as well as administrative institution. Nagari is inhabited by people who are united by the adat law and local customs which is based to the ancestral kinship relationships, consisting of clan and lineages. Nagari has also been included into the regional development agenda according to the implementation of the a long-term development plan of the regions (RPJPD 2005-2025). Even though, in the recent times, there were 754 nagari has become a measuring overall regional development, but the nagari development has not been able to achieve a result that is to be maximized, because there are still many nagaris that have status an undeveloped, such as the Bawan nagari in Agam regency, which is definitely there are many poor families (kinciakincia.com ). In Padang Pariaman Regency, there are also nagaris that undeveloped area such as the Balah Aia, in district VII of Sungai Sariak. In the Solok regency, as the famous as center rice production west sumatera, a nagari named Garabakdata, in Tigolurah district is considered less developed and touched by the march of regional development ( the Padang 
Ekspres daily, 31 / 05 / 2013). In the Tanah Datar regency, although many nagaris have reached welfare, but there are some nagaris still need to be touched in development and be optimized such as the Dadok and Taluak. Based on these cases, it shows the fact that development in the local level not yet made optimally. Factors of entrepreneurship culture and sociocultural assets can be considered to give a breakthrough alternative to build local community more prosperous.

\section{Community Development from An Anthropological Perspective}

The contents of this paper adopting the science of anthropology, especially economic anthropology. Have since middle ages of 70 s, the anthropologists who practiced (practicing anthropologist) have turned into anthropologists who directly applied their knowledge in community (applied anthropologist) in the certain areas, such as public health, development or education (Ervin, 2000). More specifically, contribution of the science of anthropology in community development in the Indonesian context is still seeking a form of actual concept of culture in various development spheres. Development for public welfare have used the development orthodox, for example by figure of Adam Smith, radical approach and growth with equity approach (Seitz,1988) It can be said has failed to build the society. Consequence of this is there should be a breakthrough to seek the development approach to be accurately targeted and efficient.

Anthropology in its knowledge implementation elaborating policy processes; evaluate the impact of policy or decision of a policy or evaluating something done because of a policy. Anthropology can also offer practical solutions for problems in development in the community. Researches in anthropology that has been used for that are implementing the methodological skills and basic research in anthropology (Koentjaraningrat, 1982; Scupin dan DeCorse, 1998: 12, Marzali, 2000: 96). Relates to development issues, anthropology specializes anthropology of development as one of the subject fields that can make developmental concepts or thoughts become more pragmatic and applicative for the construction of the community (Willigen, 1986; Ervin, 2000).

In the best interests of this paper, anthropology is used to analyze several variables that relate to development practice within the nagari that is cultures of entrepreneurship and sociocultural assets. A development process which provides an effort to grow community entrepreneurship in community is the influential form of an industry that has been included in rural scope (Guinnes and Husin 1997 ) and changing economic behavior in the community or growing modes of economic action by Olivier de Sardan ( 2005 ). Both writers (Guinnes and Husin) said the industrial development with a high capital (padat modal) who spread until to the district level and rural areas by East Java has been able to encourage development motion at the local level that is significant. The types of an industry that has appear like the food and beverage, tobacco, textile and clothing, metal and machinery, wood and furniture (Guinnes and Husin, 1997: 389). The appearing impact of an intermediate scale and small industry to the district and rural level areas are the results of spatial impact, so that giving a notion of "urban villages", and the transfer of the orientation among the young villagers to more probably work in the industrial sector rather than in the agricultural sector (Guinnes and Husin, 1997: 400). But, after the last two decades the issue started in districts and villages, development budget at the village level still does not get rid of the funds provided by the central government. It means that the development of the industry has not yet had the capability of being independent for the community to build their own region. The issue of sociocultural assets, in this context, regarded 
as a variable from the process of the dynamics of the social changes in the development (Olivier de Sardan, 2005). Among other assets in forms sociocultural is social networks, kinship relations, patron-client relationships, various patterns of social relationships, local professional and institutional relationships (Olivier de Sardan, 2005: 61).

\section{Prevailing Views on Entrepreneurship in Village development}

Many scholars has defined entrepreneurship differently, though similar substance (Rutten, 2001, Carrier, 2005, Nair and Pandey, 2006, Herberer 2007, Clamp and Alhamis, 2010). The term "entrepreneur" was coined in French economics as in the $17^{\text {th }}$ and $18^{\text {th }}$ centuries. This term is derived from the French word entreprendre means to do something or to undertake. In a general meaning, this term substantiates an engagement in business without an assurance of gaining profits or any benefits.

Entrepreneurship is regarded as a state of business undertakings and usually associated to an issue of urban industry. Entrepreneurship is also perceived as the creation and exploitation of new economic niches (Carrier, 2005: 366). The most distinguishing characteristic of entrepreneurs is their innovative nature as Schumpeterian perspective ever coined it (Nair and Pandey, 2006: 49). Clamp and Alhamis (2010) substantiate Schumpeter's idea that an entrepreneur is a change agent in the economy who either serves new markets or creates new ways of doing things. Most scholars have a red line to give understandings that entrepreneur is characterized as capital owner, market-oriented, high profile and mostly connected to the person who does entrepreneurial behavior and accustoms in the atmosphere of business competition.

Some scholars give ideas of entrepreneurship that do not always prefer to urban economic behavior as a common inclination, rather also prefer to rural people who also practice it. Taken from study of ethnic entrepreneurs in rural China (Heberer, 2007:15), the term entrepreneurs refers to villagers who founded and currently run private enterprises or who have taken over state or privately owned business that they know to manage and to develop it independently. Hence, rural entrepreneurs come up as one of a few type of entrepreneurship with demographic basis. The most characteristic of this kind of entrepreneurship is the collectivism in business activities with family basis. This collective form of businesses is conspicuously practiced among ethnic Chinese throughout regions of Southeast Asia; Indonesia, Malaysia, the Philippines, Singapore and Thailand and one of the most important factors that awakens the rise of China as an economic power in that region. It results impact on Southeast Asian states and societies as a whole (Suryadinata, 2006: 4).

Taking the case of Indian, Malaysian and Indonesian rural entrepreneurship, the positive effects of the joint family on business systems often placed a critical role in commercial and industrial activities and also its industrial success (Rutten, 2001: 170). Moreover, he argued that recently family enterprise in the rural contexts becomes burgeoning and collective form of business is quite familiar among rural entrepreneurs in these three regions. This form flourishes in the current atmosphere of globalization and free market economies (Rutten, 2001: 170).

Basically, rural entrepreneurs are derived from the particular circumstances that culture of peasantry as the backbone of their characteristics. Peasants are basically agriculturalists who rely much on natural resources for their household economy and supposedly commercial-less oriented society. They are also characterized as small-scale producers organized into a kind of household and family industrial undertakings. They mostly still rely on family labors for executing them and still overwhelmed by a typical subsistence-oriented economy that is 
nevertheless a part of a larger system (Barfield, 1997: 352). Through their involvement in the entrepreneurship, peasants always practice entrepreneurial behaviors as collective strategies in dealing with changing situation in agricultural development. In this sense, Rutten (2003) refers to peasants working on nonagricultural undertakings as the rural capitalists. Based on his comparative study on entrepreneurships and small-scale industries, market and capitalism in the rural context in these three regions, furthermore he argues that processes of politics, economy and culture constitute the historical processes of rural capitalist development (Rutten 2003:36). Earlier studies on entrepreneurship tended to stress variability, however, there are also striking resemblances in entrepreneurial behavior among villagers across the studied regions, especially in economic and social behavior (Rutten 2003: 37, 205).

Rural capitalists can rejuvenate the rural life much better in the process of rural development as a whole. They are also the newly emerging business classes that may play an important role of rural development. In relation to it, three major points may be taken into consideration (Rutten, 2003: 2-4). First, an appearance class of rural industrialists is able to express strong interests in the advancement and technological development in the rural industry. This interest gives further impact on local community for creating a new pattern of social and economic behaviors. Next, local value system still plays an important role of promoting the successful economic behavior among villagers as a whole. Finally, discussion of rural entrepreneurship focuses on a pattern of behaviors influenced by social, economic and religious systems.

In different language to refer to notion of entrepreneur or family business, Smart and Smart use term of petty capitalists. It is noticeable that peasant enterprises are small and middle scale in nature is called petty capitalist (Herberer, 2007; Gezzi, 2005). Petty capitalists regularly operate in the ambiguous boundaries between capital and labor, cooperation and exploitation, family and economy, tradition and modernity, friends and competitors (Smart and Smart, 2005: 1). From the ethnographical perspective, the authors define petty capitalists as individuals or households who employ a small number of workers but are themselves actively involved in the labor process and have internal diversity (Smart and Smart, 2005: 3-4). This term might avoid misunderstanding of term entrepreneur that includes a broad perception of entrepreneurial behaviors from everyone, from small vendors on the sidewalk up to Bill Gates. It can avoidable a misled concept of family business that mostly denotes to the size of enterprise and kinship underlying basis of entrepreneurial organization (Smart and Smart, 2005: 3). Therefore they argue that petty capitalists are an intermediary category, bounded by petty producers and subsistence producers on the one side, and by "real" capitalists on the other side (Smart and Smart 2005: 4).

All meanings of entrepreneurs explained above are categorized as traditional business entrepreneur as being contrasted to another term called social entrepreneur ( Clamp and Alhamis (2010). It is said so because such kind of entrepreneur is inclined to be a rational response to competitive pressures and is designed to generate profits for individual and organizations. Meanwhile, recent studies have attempted to reclaim entrepreneurship away from such traditions by relating it to civic and communities' needs, arguing that entrepreneurship can also create social benefits whereby firms and individuals become more responsive and responsible to their communities (Clamp and Alhamis, 2010: 153). Clamp and Alhamis divide the term social entrepreneurs into two kinds, that are civic entrepreneur and co-operative entrepreneur.

Henton, Melville and Walesh (1997) were ever addressed the term civic entrepreneur, that according to Clamp and Alhamis (2010), it may be the same as the social entrepreneur. Civic entrepreneurs have five common traits. They (1) see opportunity in the new economy, (2) possess an entrepreneurial personality, (3) provide collaborative leadership to connect the 
economy and the community, (4) are motivated by broad, enlightened, long-term interests, and (5) work in teams, playing complementary roles (Henton, Melville and Walesh, 1997: 152).

In the light of core of civic entrepreneur, they argue that civic entrepreneurs understand the new economic realities and are compelled to act on an optimistic vision of how their community can be successful in the next-century world. They believe the new economy-global, complex, and fast-changing -can provide unprecedented opportunity for people, places, and organizations. Civic entrepreneurs take their regional economy -its opportunities and needs- as a starting point and help communities make positive choices about their future, building the relationships and specialized resources for success (Henton, Melville and Walesh, 1997: 152).

Then, co-operative entrepreneur is typically a self-help economic person who serves the members of co-operative (Clamp and Alhamis, 2010:156). This kind of entrepreneur has at least four characteristics:

1. to take risks on behalf of the members to secure new opportunities for raising and securing assets for the cooperative and its members;

2. to seek access to social capital to support self help efforts of members and when needed venture capital;

3. create wealth and access to goods and services for members where they would not have access based on their own resources

4. to be co-operative in nature (Clamp and Alhamis, 2010: 158).

\section{Culture and Economy in Rural Development}

First of all, to comprehend evidence of rural entrepreneurialism, a social context of entrepreneurship should be taken into consideration. It is a crucial point to know the process of entrepreneurial behavior conducted by a person or some persons in the particular community. Thereby, the core catalyst that stimulate or inhibit practice of entrepreneurship can be studied as a kind of social reconstruction (Sheth, 2010). Being part of this argument, entrepreneurship can employ and generate social capital as much as it uses and generates material capital. It seems to me that by emphasizing social context of entrepreneurship, social capital can be analyzed as important as material capital that it is already common perceived. It means that social capital is generated and comprehended from the social context within which entrepreneurship occurs.

The next notion to substantiate rural entrepreneurialism is the interplay of economy and culture. From the anthropological perspective, Gudeman has presumably argued that economy as culture (Gudeman 1986). The importance of cultural perspective as an alternative model to understand the economic patterns of various peoples in the world is very crucial as universal model of economic explication is not satisfied to explain various economic behavior from one society to another in the world. This idea is posed in two important questions by Gudeman:

1. What constructs or model are appropriate for analyzing the economic patterns of other societies?

2. Should we employ our Western categories of knowledge or must other ways of knowing and understanding be used?

It is very vivid that Gudeman argues that economies and economic theories are social constructions. By that means, the central processes of making livelihood are culturally modeled (Gudeman, 1986: vii). The author's aim is to analyze models of livelihood as cultural construction. 
After that, the notion of embeddedness is predominantly accepted by anthropologists to embody economy, or in this sense entrepreneurship, in the social or cultural context. Basically, Polanyi has led anthropologists to put economy as substantive paradigm as being contrasted to formal economic paradigm. In this sense, economy is institutionally embedded into social structure. By using concept of embeddedness elaborated furthermore by Granovetter, economic actions heavily occur in the context of social structure, or, practically, in social relations (Granovetter, 1992: 53). In this sense, culture and economy are mutually related to each other.

Another perspective that draws on discourse of rural entrepreneurialism in the peasant economy is the collective form of business activities. In the rural context, this form is easily found out in the social context of ethnicity. Two current issues that support this perspective is provided by Eriksen's economies of ethnicity (Eriksen 2005) and by Gudeman's integration of community, market and culture (Gudeman 2001). Eriksen argues that, firstly, the ethnic differences may be seen as a result of cultural differences, in that, each group possesses certain cultural resources making its members particularly well equipped to undertake particular forms of economic activity by choice, by tradition or both. Secondly, the differences may also be seen as a result of structural factors, such as systematic power differences, that channel the economic activities of different group in certain ways (Eriksen, 2005: 353).

Meanwhile, Gudeman argues that economy consists of two realms which are community and market (Gudeman, 2001: 1). These two realms constitute functionally any economic practices and relationships. Furthermore, he states that an economy community makes and shares a common that is termed as the "base" or "foundation" (p.27). The base is a commons consisting of the material thing or knowledge a people have in common, what they share. The base is regulated also through moral obligations that have the backing of powerful sanctions (Gudeman 2001: 28). By understanding of the base, the community economy is predominantly based on values sources from the community culture. In this sense, Gudeman gives a sense of economy at the base. Based on these arguments, I adopt these two perspectives to strongly argue that rural entrepreneurialism built by dynamic support of local culture.

To examine these perspective of position of rural entrepreneurialism in community, Dunham's study about the Javanese blacksmithing can obviously represent rural entrepreneurialism cannot be apart from social and cultural contexts of Javanese ethnicity. Peasant blacksmithing in this community cannot be contrasted with the types of blacksmithing that have been emerging in the European context since many centuries ago. Javanese cultural values and less-innovated entrepreneurial behavior among blacksmith made this rural industry could not highly develop become a manufacturing industry. Thereby, I come across to the argument that Javanese rural entrepreneurs is embedded in their Javanese ethnic identity and, supposedly, social norms. This embeddedness brings about the typical economic behaviors and peculiar rural industry as a whole. Dunham argued that most Javanese blacksmithing emerge not only in the context of peasant society in Indonesia, but also it emerges in the context of local ethnic identity (Dunham, 1992 [2008]: 33). Dunham's study on blacksmithing convinces us about practice of commercialization in the context of local ethnicity and also in local values as a whole. In a similar line with this argument, Kahn argues that the creation of commercial occupation; such as that of blacksmith, carpenter, tailor, wage laborer, etc, in the village society is proposed as a reaction to the market expansion into the local community and culture (Kahn 1980). Kahn studies on the Minangkabau peasant blacksmithing shows that contextualization of rural industry to the social and cultural body is quite obvious. The most Minangkabau peasant, who are blacksmithing, respond also market economy by means of their ethnic identity.

In tune with above arguments, from the anthropological perspective, it is important to notice of what Eriksen argued that ethnicity becomes an important part of reconstruction of economic 
structure of particular community, and it concerns with processes of social identification and identity politics rather than economic processes per se (Eriksen, 2005: 353).

Lastly, in order to substantiate the insights above, the following parts will present three empirical case studies on how, to some extent, the social and cultural contextualization, or economy and culture are related to each other, of rural entrepreneurialism is practiced by some entrepreneurs. These case are taken from the study on ethnic entrepreneurs who are from Javanese and Minangkabau ethnic groups.

In the light of Polanyi's argument (1992), economy is institutionally embedded in social structure is fully accepted. However, as regards entrepreneurial behavior is burgeoning in the rural areas due to excessive development of market economy, on the other way around, social structure is inevitably embedded in the changing economic system. Therefore, still in the light of Polanyi's notion, I argue that social structure is inclined to be impaired whenever economic changes take place. How to notice this circumstance? It can be indicated by the flourishing entrepreneurial behavior in the rural area within which people are inclined to being outgoing from their own ethnic community in the village (case 1 and case2 ) rather than remaining in their community. In the case 1 and 2 the rural entrepreneurs were migrating from own ethnic community to another ethnic community. Meanwhile, the case 3 shows how entrepreneurial behavior is exploited in the context of own rural community without any clear indication whether such behavior still in the line of ethnic tenet. This case can come across of maximizing gains in any economic chances in own community is supposedly well acceptable. Based on these cases, that rural entrepreneurialism is developed from non-capitalist economic system to the market economy that is inclined to be exploitative.

Over the years Chayanov's perspective on non-capitalist economic system in agricultural development used to overwhelm the perspective of peasant societies in terms of collectivism, non-wage family labor and non market rural communities. Nowadays, in the context of world capitalism, all people have plunged to the different economic circumstances. Some scholars have argued that peasants and their rural economy are inevitably incorporated into a market economy (Wolf, 1966; Kahn 1980; Elson 1984; Buchholt, 1989; Geertz, 1992; Effendi, 2005). Peasants do not longer rely mainly on their own agricultural investment to meet their subsistence needs, instead they are mostly dependent much on market for exchange of agricultural and non agricultural products, actualizing status and social roles, involving in changing style of consumption. In this sense, the peasant market provides multiple functions that of (1) outlet of peasant's own agricultural products as inlet of out local products, (2) space of social and cultural expression embedded in business activities, (3) intermediary local economic institution to a broader economic institution that makes village space as integral part of urban and, even, global interests (Effendi, 2005). It can be said no doubt that peasant economy is culturally inclined towards incorporation in market economy.

In tune with this changing peasant economy, it is necessary to emphasis rural enterprises and the role of social institutions and cultural values deals with such changes. It is noted that rural enterprises have shifted from household economy to small-scale industries and from family member's labor dependency to the skilled labors and mechanism of division of labor. These changes may be elaborated by emphasizing on considerable attention to the central concept of patterns of exchange and distribution in peasant economy (Ensminger 2002: xiv), of property rights and incentives for agricultural growth (Gwako, 2002), commodity flows and the evolution of complex society (Earle 2002) and economic transfers and exchanges (Hunt 2002).

In spite of peasant economy deployed by petty capitalists, principle of capitalism, in the sense of market economy, is very crucial to substantiated. As regards substantive perspective, Polanyi regarded capitalistic economy as instituted process. It should start from the 
interdependence and recurrence of its parts that are combined by patterns of reciprocity, redistribution and exchange (Polanyi, 1992: 35). Bell noticed that capitalism is a system of traders and merchants, or, entrepreneurs, seeking profitable opportunity. This kind of capitalism refers to the market processes as Polanyi has developed in his work the great transformation (Bell, 2002: 121). At least, I argue that current peasant economy may be represented practically by the use of capitalistic principle but in the small-middle scale enterprises.

By so argument, putting the discussion of peasant economy first in the current village development, someone should find out the dynamics of small-middle scale enterprises, rural market, and changing behaviors of household economy. This dynamic economy has pulled peasants from permanently dependent on agricultural and natural resource exploitative undertakings to the full-business activities. Therefore, the present peasant economy tends to be a variant of commercial-based economy and subsequently, it will link to the broader economy institutions, like a global market economy.

Studies on peasant blacksmithing (Kahn, 1980; Dunham 1992 [2008]) have given a hint that such changes of peasant economies disturb the major ethnic identity. Whether the blacksmithing activities perform ethnic ideas to collective form of organization, meanwhile they implemented a such kind of division of labor in blacksmithing works. In Javanese and Minangkabau villagers, on farming works tends to decline and shift to the non farming enterprises. These people establish rural capitalism with the basis of petty steel industry. Collective forms of organization vary from one blacksmith to another in terms of division and amount labors, capital sharing, and networks. Therefore, it is rather obsolete to argue that peasant economy still represents an ethnic subsistence in their enterprise. By so arguing, peasants accustom themselves to the market culture within which ethnicity can up and down dealing with market challenges.

As linked to comprehensive studies in the Asian society, Hefner contributes an understanding the market culture (Hefner 1998). According to him, market culture gives notions of constituting economy and culture through market processes. In this process, the relative compatibility of local culture with modern capitalism takes place in the way in which religion, ethnicity, gender and class play also an important role (Hefner, 1998: 3). In this sense, it is noticed that the position of ethnicity is still remained in the market culture. I argue that this understanding might construe an argument that market culture is actually entangled in the market economy in nature.

In the light of Dunham's and Kahn's cases and the three cases above, there were evidences that peasants have developed various behaviors in their enterprises between market importance and ethnic substance. This can be seen likely as a pendulum swing. Market and ethnicity sway across from one point another depending on the its demand.

Some important issues in relation to the market culture show up, that of, firstly, peasant blacksmithing does not only fully represent activities of rural economy, but also ethnicity (Dunham, 1992 [2008]: 33). Secondly, there are cultural differences are between practices of the so-called rural industrialism and western industrialism. Therefore, rural entrepreneurs cannot ever adopt type of organizational industrialism as developed by the West. Industrialism in peasant societies will not automatically lead to the process of ethnic tenet eliminated. Thirdly, as a result, cultural dimension in rural blacksmithing industry still plays also an important role. This dimension is indicated by the local values and symbolic associations attached in the blacksmithing and all art crafts produced from the works (Dunham 1992 [2008]: 113). Fourthly, most peasant blacksmithing were always pictured as a certain working class and small-middle scale entrepreneurs that are routinely suffered from lack of capital and income. They perform works as just what they are, even though, they develop a kind of capitalistic industry. Lastly, 
by emphasizing on the deep description on place of workshop of blacksmithing at the research setting, Dunham's study may reveal practice of local wisdom value of technological dimension in blacksmith works.

The Kahn's case of Minangkabau peasant blacksmithing shows the global connection to the local peasant economy. His argument is that the only obvious direct contact of the Minangkabau world with the global economy is through the local or regional market and that it is clear that the Minangkabau village is closely linked economically to the outside world. (Kahn 1980: 27, 75). Further more, Kahn argues, based on his study of blacksmiths in Sungai Puar nagari, that the emergence of petty commodity production in west Sumatra, by the turn of this century, reveals the involvement of the Minangkabau in the international trade network (Kahn 1980). In addition, Kahn noted that the existence of petty commodity production is equally dependent upon the world market. Nevertheless, the world economy is the precondition for, but not the cause of, all different forms of commodity production within it (Kahn 1980: 208). This is that I want to conceptualize as a form of local and global connection by means of local products inserted in the global market.

In the context of a global connection, the perspective of rural and urban dichotomy is sociologically irrelevant. No village is physically isolated to outer space and broader economic interests. No villager also feels isolated to broader societies. Urban and rural borders become blurred by definition as a result. What are available physically in the city is also partly available in the village. Urban life style is also found out in the village life. It is a basic argument to understand rural development is closely connected to the urban and global dynamics in terms of economy, social, culture, and technology.

Modernization in the village world is a marker of ongoing changing life, social and economic behaviors in the rural areas. In the 1950s, take a look at the case of Clifford Geertz study on Javanese villagers, he believed that Java had failed to industrialize because its traditional values had never given way to modernizing ones. He also argued that the Javanese a generalized non-entrepreneurial, non-innovative cultural attitude and made this supposed cultural traits the proximate cause for Indonesia's failure to industrialize (Geertz, 1955 in Gilman 2002: 7). He gave also an argument that involution tended to quash entrepreneurialism and any sustained economic growth would have to be state-led (Gilman, 2002: 12). However, Geertz's insight to this Javanese rural development misled, if Dunham's study on Javanese blacksmithing is compared. Dunham understood Javanese village development differently as Geertz argued.

According to Dunham, blacksmithing is a form of rural industries that brings rural people becoming somewhat industrialist, and, even capitalist. Rural industry by means of blacksmithing has own particular socio economic order (Dunhamm 1992 [2008]: 120). This order depicts the existence of social differentiation, such as working class, capital owner, trader, distributor, supplier, etc. Social and economic complexity in the rural industry concerns with the consequence of a modernization in the village world.

How does this kind of modernization take place in rural context in Indonesia? Village is the place of land and agricultural sources. However, the modernization in the village needs networks with the broader economic actors. These actors are available in the urban areas. Therefore, intervention of urban economic actors moves rural industry forward. In this sense, it is argued that the connection of rural and urban economies is absolutely needed by means of migratingThen, it can be understood that the connection between rural industry and global world is also inevitable as a consequence.

The incorporation of rural enterprises in the market economy and subsequently into global connection awakens the awareness of the importance social process to follow step by step 
ongoing changes among the rural communities. What happens to such kind of social process of rural communities? Is it the process of incorporation always coming up with integrative or conflict interplay? Is it possible that the process deal with tensions in terms of interests, actions, or whatever?

In the context of rural entrepreneurialism, small-middle scale of enterprise defines as a sum of entrepreneurial actions by agencies who implement different ideas, such as ethnic norms or identities, economic calculation, or pragmatism, for meeting capitalistic objectives. These ideas may be practiced in the positive interplay, or, also be in the negative one. In the classic perspective of peasantry, peasants commonly represent collective solidarity (Redfield, 1968) and generalized reciprocity (Bohanan and Dalton, 1962). It seems to be that peasants are reluctant to generate social conflict, rather social integration, dealing with contradictory interests among them. Platter (1989) regards this situation as an aversion risk of action. However, peasants are not figured out of a single pattern of actors with their homogenous norms and values. It is put classically by Scott (1976) as an issue of moral economy that insists peasants on dialectical options in their agricultural activities. Peasants should deal with changing situation in terms of economic and agricultural undertakings in the villages. Capitalistic penetration from outside can draws on peasant to find alternative ways deals with their agricultural economy. In this sense, conflict potentiality may rise among the peasant actions. Social structure might be also shaky.

Putting issue of ethnicity in peasant economic enterprise, it is argued that peasants allegedly maintain their social integration through their ethnic norms or collective forms of social organization in the midst of penetrating rational choice of economy. In this sense, there is conflicting ideas of economy and ethnicity in the peasant society. It might be related to the what Gudeman (2008) argues on dialectics of community and market.

Gudeman addresses issue of dialectics of local and universal models for economy. Local models are contextual formulations and have no fixed form and are unfinished as ways of constituting action within an environment that exceed their specification. Meanwhile, a universal model is self-contained, derivational in form, and apparently complete. Moreover, it seems to be independent of all local conditions (Gudeman, 2008: 15). Gudeman explains deeper and more extensive about these models (page $15-21$ ).

Finally, I argue that the conflicting interests among rural communities can arise if the position of economic tenet is too predominant, meanwhile the moral economy is put aside. Meanwhile the social integration can be maintained as long as rural entrepreneurs practice a principle of social entrepreneurship. 


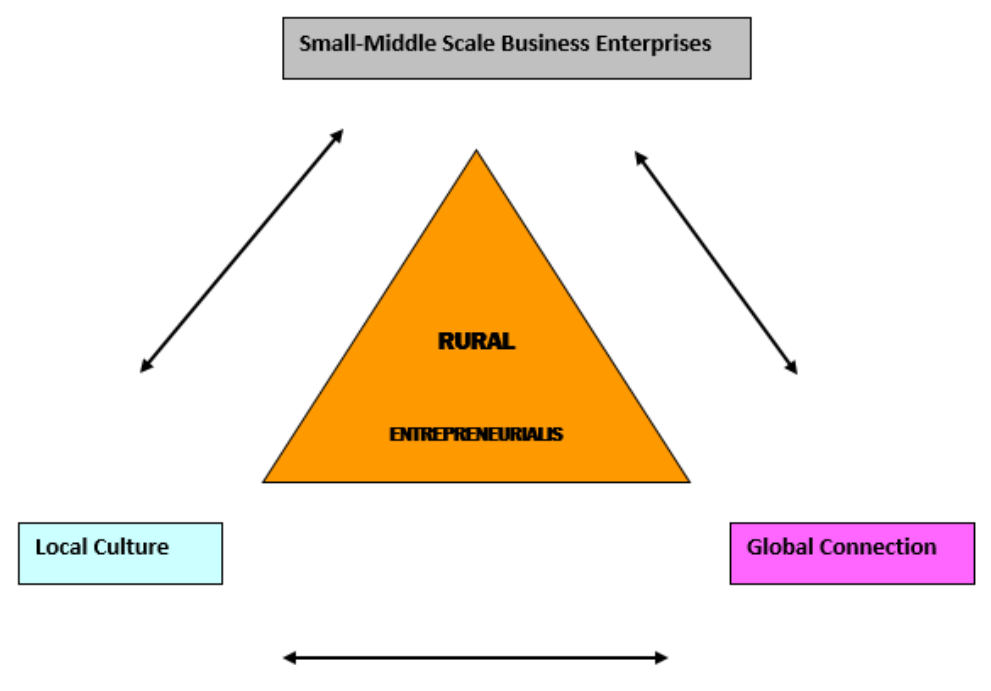

Fig. 1. Diagram of Interplay of Rural Entrepreneurialism Factors

\section{Conclusions}

Village development in Indonesia needs interwoven supports among governmental regulations, entrepreneurial culture and the use of sociocultural assets. Rural entrepreneurialism, market economy, and market culture are the major domain to look at the changing circumstances of rural society today. This is a suitable element to state a village condition of development. By this means, rural areas are the place of social, economic and developmental dynamics in that culture still plays an important role in it, though is not consistent. Consequently, village area is no longer isolated due to open-minded community toward changing situation, even though it is dependent much on governmental intervention in development, but their local culture is still maintained as well.

Rural entrepreneurialism is developed by capacity building of small-middle scale enterprises. In this business, actors practice particular social and economic behaviors that are constitutively induced from their own local culture. However, it misleads to understand rural industry replicates the industry in the West. Rural industry emerges, develops and sustains on the basis of local culture. It means that the social construction become conspicuous as the main context to see the long process of rural entrepreneurialism is incorporated into the market economy.

Even though rural entrepreneurs have already incorporated into the conflicting in the economic interests in dealing with developmental process, the position of ethnic identity still exists though shaky. The vulnerability of ethnicity as the major tenet to guide rural entrepreneurialism still on the local culture track is questionable. Therefore, the further study on the what extent development can threaten the ethnicity, and on what level ethnicity remains in its position to strengthen rural entrepreneurs, therefore ethnicity still being a social harness. 


\section{References}

Barfield, Thomas (ed). 1997. The Dictionary of Anthropology. Oxford: Blackwell Publisher

Bell, Duran. 2002. "Polanyi and the Definition of Capitalism". In: Theory in Economic Anthropology. edited by Jean Ensminger. New York: Altamira Press

Bohannan, Paul and George Dalton. Eds. 1962. Markets in Africa. Evanston, Ill.: Northwestern University Press

Buchholt, Helmut. 1989. Exchange and Trade Under a Regional Perspective: The Great Transformation in Minangkabau/Indonesia? Working Paper SDRC University of Bielefeld, Nr. 126

Carrier, James G..2005. A Handbook of Economic Anthropology. Cheltenham, UK:

Edward Elgar

Clamp, Christina A. and Innocentus Alhamis. 2010. 、 Social Entrepreneurship in the Mondragon Cooperative Corporation and the Challenges of Successful Replication. In Journal of Entrepreneurship., 19, 2, p. $149-177$

Dunham, Stanley Ann. 1992 [2008]. Pendekar-Pendekar Besi Nusantara: Kajian Antropologi tentang Pandai Besi Tradisional di Indonesia. Bandung: Mizan

Earle, Timothy. 2002. "Commodity Flows and the Evolution of Complex Societies". In Theory in Economic Anthropology. edited by Jean Ensminger. New York: Altamira Press

Effendi, Nursyirwan. 2005. Minangkabau Rural Markets: Trade and Traders in West Sumatra, Indonesia. Muenster, Germany: LIT Verlag

Ensminger, Jean (ed). 2002. Theory in Economic Anthropology. New York: Altamira Press

Elson, R.E..1984. Javanese Peasants and the Colonial Sugar Industry: Impact and Change in East Java Residency: 1830-1940. Singapore: Oxford University Press

Ensminger, Jean. 2002. Theory in Economic Anthropology. New York: Altamira Press

Eriksen, Thomas Hylland. 2005. "Economies of Ethnicity". In: A Handbook of Economic Anthropology. Edited by: James G. Carrier. Cheltenham, UK: Edward Elgar

Evers, Hans-Dieter and Heiko Schader. (eds.). 1994. The Moral Economy of Trade: ethnicity and Developing Markets. London: Routledge

Evers, Hans-Dieter. 1996. „Globale Märkte und Soziale Transformation“. In: Weltsystem und kulturelles Erbe: Studien zur Sozialanthropologie. Edited by G. Mueller. Berlin: Reimer

Geertz, Clifford, 1963. Peddlers and Princes: Social Change and Economic Modernization in two Indonesian Towns. Chicago: Univ. of Chicago

Geertz, Clifford. 1992. "The Bazaar Economy: Information and Search in Peasant Marketing”. In The Sociology of Economic Life. Edited by: Mark Granovetter and Richard Swedberg. Oxford: Westview Press

Ghezzi, Simone. 2005. "Global Market and Local Concerns: Petty Capitalists in the Brianza". In Smart, Alan and Josephine Smart (eds). Petty Capitalists and Globalization: Flexibility, entrepreneurship and economic development. New York: State University of New York Press.

Gilman, Nils. 2002. "Involution and Modernization: The Case of Clifford Geertz". In Economic Development: An Anthropological Approach. Edited by: Jeffrey H. Cohen and Norbert Dannhaeuser. New York: Altamira Press

Granovetter, Mark. 1992. "Economic Action and Social Structure: The Problem of Embeddedness". In The Sociology of Economic Life. Edited by: Mark Granovetter and Richard Swedberg. Oxford: Westview Press

Gudeman, Stephen. 1986. Economics as Culture: Model and Methapors of livelihood. London:

Rotledge \& Kegan Paul

Gudeman, Stephen. 2001. The Anthropology of Economy. Oxford: Blackwell Publishing

Gudeman, Stephen. 2008. Economy's Tension: The dialectics of Community and Market. New York: Berghahn Books

Gwako, Edwins Laban M. 2002. “Property Rights and Incentives for Agricultural Growth: Women Farmes' Crop Control and Their Use of Agricultural Inputs. In: Theory in Economic Anthropology. Edited by Jean Ensminger. New York: Altamira Press

Heersink, Christian G..1994. "Selayar and the Green Gold: The Development of the Cococnut Trade on Indonesian Island (1820-1950)". In Journal of Southeast Asian Studies. 25, I, March 
Herberer, Thomas.2007. Doing Business in Rural China: Liangshan's New Ethnic Entrepreneurs. Seattle and London: University of Washington Press

Hefner, Robert. W. (ed). 1998. Market Culture: Society and Morality in the New Asian Capitalism. Colorado: Westview Press

Hunt, Robert C..2002. "Economic Transfer and Exchanges: Concepts for Describing Allocations". In: Theory in Economic Anthropology. edited by Jean Ensminger. New York: Altamira Press

Kahn, Joel S. 1980. Minangkabau Social Formation: Indonesian Peasant and the World Economy. Cambridge: Cambridge University Press

Nair, K.R.G. and Anu Pandey. 2006. "Characteristics of Entrepreneurs: An Empirical Analysis. In Journal of Entrepreneurship. 15, p. 47

Plattner, Stuart. 1989. Economic Anthropology. Stanford, California: Stanford Univ. Press

Polanyi, Karl. 1992. "The Economy as Instituted Process". In The Sociology of Economic Life. Edited by: Mark Granovetter and Richard Swedberg. Oxford: Westview Press

Rutten, Mario. 2001. Family Enterprises and Business Partnerships: Rural entrepreneurs in India, Malaysia and Indonesia. In Journal of Entrepreneurship. 10, p. 165

Rutten, Mario. 2003. Rural Capitalists in Asia: A Comparative Analysis of India, Indonesia and Malaysia. London: RoutledgeCurzon

Scott, James C. 1975. Moral Ekonomi Petani. Jakarta: LP3ES (Indonesian Translation from The Moral Economy of Peasants)

Scott, James C. 1995. Senjata Orang yang Kalah. Yogyakarta: Pustaka Pelajar (Indonesian Translation from Weapon of the Weak)

Sheth, N.R. 2010. The Social Context of Entrepreneurship. In The Journal of Entrepreneurship, 19, 2 : 99-108. Sage Publication Los Angles/London/New Delhi/Singapore/Washington DC.

Smart, Alan and Josephine Smart (eds). Petty Capitalists and Globalization: Flexibility, entrepreneurship and economic development. New York: State University of New York Press.

Suryadinata, Leo (ed). 2006. Southeast Asia's Chinese Businesses in Era of Globalization: Coping with the Rise of China. ISEAS: Singapore.

Wolf. Eric. R..1966. Peasants. Englewood Cliffs New Jersey: Prentice-Hall, Inc 